\title{
AZ ÖNKÉNTES SZERVEZETEK LEHETSÉGES SZEREPE A KÖRNYEZETI KÁRESEMÉNYEK MEGELŐZÉSÉBEN ÉS AZ ELLENÜK VALÓ REZÍLIENCIA KIALAKÍTÁSÁBAN
}

\section{DEVELOPMENT OF THE PREVENTION OF ENVIRONMENTAL DAMAGES BY INVOLVING VOLUNTARY ORGANIZATIONS}

\author{
LESKÓ György; \\ (ORCID: 0000-0001-7470-7824) \\ Lesko.Gyorgy@uni-nke;
}

\begin{abstract}
Absztrakt
A környezetvédelem kérdése napjainkban a fókuszba került, hiszen gyermekeink jövője nagyban függ attól, hogy meg tudjuk-e örizni számukra az élethez szükséges természeti kincseket. A környezet-szennyezést okozó káresemények száma évről évre nő, egyre több formában és módon veszélyeztetjük a környezetünket. Az éghajlatváltozás ezt a helyzetet súlyosbitja. A társadalom alapvetó érdeke, a fenntartható fejlődés biztositása. $A$ környezeti ártalmak elleni védekezés leghatásosabb eszköze a megelőzés, ami széles társadalmi támogatás és az önkéntes szervezetek tevékenysége nélkül napjainkban már nem valósitható meg sikeresen. Ugyanez elmondható a rendkívüli események kialakulásakor a károk felszámolását célzó tevékenységre is. A szerzö, a cikkben vizsgálja, hogy milyen szerepük lehet az önkéntes szervezeteknek a megelözés és a veszélyeztetö tényezökkel szembeni reziliencia kialakításában, és hogyan fejleszthetők humán-erőforrás tekintetében.
\end{abstract}

Kulcsszavak: környezetvédelem, megelözés, önkéntes szervezetek, fenntartható fejlödés, reziliencia

\begin{abstract}
The environmental protection issue is obviously in focus of public interest. The number of returning to environmental pollution incidents is increasing every year, more and more invisible impacts is appeared in this area. The fundamental interest of society is ensuring of sustainable development. The most effective instrument of the protection against environmental hazards is the prevention which cannot be successfully achieved without widespread social support and the activities of voluntary organizations. The author in this article investigate the development of the possibilities and praxis of prevention through the involvement of volunteers.
\end{abstract}

Keywords: environmental protection, prevention, voluntary organizations. sustainable development, resilience, 


\section{BEVEZETÉS}

A természet és a környezetét átalakító ember viszonyát, a Bükk-hegység egyik kutatója Kaán Károly ${ }^{1}$ már a század elején megfogalmazta meg legszebben Természetvédelem és a természeti emlékek c. könyvében [1] „Az ember kultúrájának anyagát kezdettől fogva a természet ös-forrásaiból merítette, mintáit az örök természet nagyszerü formáiról vette! Mégis az emberi kultúra többé-kevésbé mindenütt, és hosszú időkön át, a természeti alkotások pusztulása nyomán keletkezett.” Az idézet jól tükrözi, hogy már a megelőző század természetismerő, szerető emberei is tudták, hogy felelősséggel tartoznak a következő generációknak, mind az értékek megőrzése, mint a fenntartható fejlödés területén. Természetesen az akkori viszonyok közt is érzékelhető volt a megoldások keresése, és a környezettel harmóniában élni akaró emberi közösségek támogatásának fontossága. A természet értékeinek megőrzése nemcsak a hatóságok feladata, szerepe van benne az állampolgároknak és az állampolgárok szervezett csoportjainak, a civil szervezeteknek is. Jó példa erre [2] az októberben megrendezett Zöldgömb Fesztivál. Az esemény szakértő előadók és civil szervezetek segítségével került megrendezésre. A szervezők pozitív példákat és információkat nyújtottak a résztvevőknek a következő témákat érintve: hightech (,zöld”-energia, intelligens otthon, zöldház, elektromos jármüvek), múlt és hagyomány (talajkímélő földmüvelés, permakultúra, biokertészet, gyógynövények, tájfajták), megosztáson alapuló gazdaság, közösségi összefogás.

Jelentős vita zajlik az éghajlatváltozás okairól és következményeiről napjainkban. A tapasztalt éghajlati anomáliák (heves esőzések, az évszaktól eltérő, gyorsan változó magas, vagy alacsony hőmérséklet, extrém szélviharok) erősen foglalkoztatják mind az érintett lakosságot, a kutatókat, mind a szakembereket. „Egyre nyilvánvalóbb, hogy létrejött egy helyzet, egy környezeti állapot, aminek csakis egységesen, jól átgondolt módon és konkrét gyakorlati lépésekkel enyhithetjük a következményeit, illetve hosszabb távon talán majd megállithatjuk, esetleg megfordithatjuk a negativ tendenciákat" [3; 402. o.] állapítja meg Földi László tanulmányában. Áttekintve az erről szóló irodalmakat, megállapítható, hogy az írások föként két folyamat következményeként értékelik az éghajlatváltozás okait. Egyrészt az emberi természetátalakító tevékenység következményeként, másrészt a ciklikus éghajlati-földtörténeti folyamat részeként. Valószínüsíthető, hogy mind a két hatás jelen van a folyamatokban. Mindkettő létezésére vannak igazolható tények. A kutatásom azonban nem ezen eltérő vélemények eldöntésére irányul. Az nyilvánvaló, hogy a szakpolitikák, azon belül a klímapolitika részeként kell kezelni ezt a kérdést, és minden eszközzel törekedni kell a megelőzésre, valamint a lakosság védettségének kialakítására. Az időjárási anomáliák következményeinek kezelésére a klímapolitika ma két, jól elválasztható feladatrendszert ismer, az emberi tevékenység megváltoztatásával a káros kibocsátások és hatások csökkentését éghajlatváltozás negatív hatásaival szembeni védekezést, a rugalmas alkalmazkodási stratégiák kialakítását.

Felmerül a kérdés, hogy milyen válaszokat ad a társadalom a fenntartható fejlődést veszélyeztető tényezőkre, és a jelenlegi civil önkéntes rendszer ehhez hogyan járul hozzá, továbbá, hogyan tehető hatékonyabbá a munkájuk? Hogyan lehet a társadalom kihasználatlan erőforrásait kiaknázni, és milyen eljárásmódokat lehet alkalmazni? A fenti kérdésekre adódandó válasz megfogalmazásához, meg kell vizsgálni a jelenlegi tényezőket, a civil társadalom környezeti biztonságra való törekvésének lehetséges fajtáit, valamint a környezetvédelem önkéntes támogatásának helyzetét. Elemezni szükséges, környezetvédelmi

\footnotetext{
${ }^{1}$ Kaán Károly (Nagykanizsa,1867. - Budapest, 1940.) magyar erdőmérnök, gazdaságpolitikus, a Magyar Tudományos Akadémia levelező tagja. Nevéhez füződik a magyarországi erdőgazdálkodás újjászervezése, az Alföld fásítási programja és a korszerü állami természetvédelem megszületése.
} 
szakterületek jellemzőét, számba kell venni a lehetséges feladatokat, igazolva azok folyamatjellegét, és az átfogó megközelítés fontosságát e témakörben. Fontos kérdés, hogy a hatékony munkához milyen képességekkel kell rendelkezniük az önkénteseknek az új kihívások kezelése területén a rendkívüli környezeti káresemény-helyzetek megelőzésének, elhárításának, a fenntartható fejlődés biztosítása érdekében. Ebben a kutatásban a fenti kérdések megválaszolása érdekében célul tűztem ki, hogy vizsgálom, hogy

- milyen tényezök veszélyeztetik napjainkban és várhatóan a jövőben a környezet biztonságát és a fenntartható fejlődés folyamatosságát,

- mit jelent és hol helyezkedik el a védelmi rendszerben reziliencia ${ }^{2}$, (a környezetvédelmi rugalmas alkalmazkodás)

- mi a szerepe az önkéntes szervezeteknek a reziliencia kialakításában, és milyen eszközökkel növelhető a humán-erőforrásuk.

A környezeti káresemények elleni védekezés, a fenntartható fejlődés biztosítása össztársadalmi érdek, és feladatrendszer, amelyben mind a közigazgatás (védelmi igazgatás) és a beavatkozó állami, mind a feladatban résztvevő önkéntes szervezeteknek jelentős szerepe van. Ezért várhatóan a kutatás eredményei hozzájárulhatnak a fenntartható fejlődés feladatainak végrehajtásához, és a környezetvédelem állami, és önkéntes szervezetei együttmüködési kérdéseinek továbbfejlesztéséhez és hatékonyabb munkájához.

\section{A kutatás és az alkalmazott módszerek leírása}

A vizsgált kérdésekről feltételezem, hogy a környezet biztonságára, és a fenntartható fejlődésre ható tényezők jelentősen, és gyorsuló ütemben változnak, párhuzamosan a technológia, és a társadalom változásaival. Ezen változásokat és hatásaikat mind a hazai, mind a nemzetközi szakirodalom, sokszor eltérően kezeli, tehát szükséges a szakirodalom elemzése, az eltérő vélemények összevetése, valamint a civil szervezetek képességeinek vizsgálata annak érdekében, hogy meghatározható legyen a lehetséges szerepük a veszélyeztető tényezőkkel szembeni feladatok végrehajtásában. A kutatás módszerét tekintve alapvetően az analízismódszerre épült. Összegyüjtöttem és tanulmányoztam a vonatkozó hazai és a nemzetközi tudományos szakirodalmakat, a környezeti káresemények esettanulmányait, valamint a témával kapcsolatos jogszabályokat, és a szakpolitikai szabályzókat, majd ezek elemzése alapján vontam le következtetéseket és tettem javaslatot. A civil szervezetekre vonatkozóan másodlagos adatok gyüjtésével és elemzésével kiegészítettem az elsődleges kutatást, végül az indukció-módszer alkalmazásával vontam le a következtetéseket. A szakemberekkel történt megbeszélések alkalmazásával szerzett információkat és a saját szakmai gyakorlatom tapasztalatait használtam a vizsgálandó témakör jelenlegi helyzetének változásainak megismeréséhez, és fogalmainak azonosításához, valamint a részkövetkeztetések meghozatalához.

\footnotetext{
${ }^{2}$ Egy veszélyeknek potenciálisan kitett rendszer, közösség vagy társadalom azon kapacitása, amely

alkalmazkodását segíti elő azáltal, hogy ellenáll vagy változik annak érdekében, hogy fenntartsa müködésének és struktúrájának elfogadható szintjét. Egyesült Nemzetek Szövetsége a Nemzetközi Katasztrófa

Kockázatcsökkentési Stratégia (UNISDR) (UN 2005, p. 4)
} 


\section{A KÖRNYEZET BIZTONSÁGÁT ÉS A FENNTARTHATÓ FEJLŐDÉS FOLYAMATOSSÁGÁT VESZÉLYEZTETŐ TÉNYEZÖK, KÜLÖNÖS TEKINTETTEL AZ ÉGHAJLATVÁLTOZÁSSAL ÖSSZEFÜGGÉSBE HOZHATÓ KATASZTRÓFÁKRA}

A környezet biztonságát és a fenntartható fejlödés akadályait vizsgálva megállapítható, hogy számtalan tényező szennyezi, veszélyezteti, vagy terheli túl a környezetet. Gondoljunk csak az esőerdők kiirtására, a káros kibocsátásokra, a túlzott és ésszerütlen energiahasználatra stb. Következőtökben kialakulhatnak katasztrófák is. Ezeket a hatásokat és a környezet rombolását csak fokozzák a katasztrófák. A biztonság aktuális kérdéseit a napi politika szerte a világban sokszor háttérbe szorítja, de a mindennapjainkra ható konkrét ártalmak, mint az éghajlatváltozás, a szélsőségessé váló időjárás, és az éghajlati anomáliák, a társadalom és a védelmi szakterület érdeklődésének fókuszában marad. A környezeti hatásmechanizmusokra épülö klímapolitika, fontos része a közérdeklődésnek. A napi sajtó ritkán elemzi egy társadalmi kérdés hírhátterét (migráció, helyi háborúk stb.), de a legtöbb aktuálpolitikai hír visszavezethető a környezetvédelemi, és ezen belül az éghajlatváltozással összefüggésbe hozható okokra. Okok és okozatok rendszerével kell számolnunk. A mai termelésnövelésére és profitszerzésre épülö társadalmak, a hatásos környezetvédelmi intézkedések mellett is nagyrészt a fenntartható fejlödés ellen hatnak. A tendenciákat és az éghajlatváltozás veszélyeit nehéz elöre jelezni, mert a természet rendszeresen rácáfol a prognózisokra.

Rendszeresen találkozunk a fenntarthatóság, és a fenntartható fejlődés fogalmával. A tartósan követhető környezettudatos fejlődési pálya megvalósítása, ami biztosítja, hogy a fejlődés következtében, nem éljük fel a későbbi nemzedékek létezésének erőforrásait, és a természeti környezet átmentésének lehetőségeit nehéz sok összetevővel rendelkező nemzetközi összefogást igénylő feladat. A megvalósítást nehezítik a katasztrófák hatásai is. A rendszerszintű integrált biztonsági megközelítés szerint az általános biztonságpolitikának része a környezetbiztonság, szoros összefüggés feltételezhetö, a természeti és civilizációs katasztrófák hatásai és az ellenük megvalósítható védelem müveleteivel, mivel ezek jelentős hatást gyakorolhatnak a környezet különbözö összetevőre.

Az elmúlt időszak katasztrófa-eseményeinek értékelését több kutatás elvégezte. Peter Mucke szerint egyre felkészültebbek vagyunk a természeti katasztrófákra. A Bündnis Entwicklung Hilft német szervezet 171 országra vonatkozóan mutatja be, hogy milyen kockázata van annak, ha egy szélsőséges természeti jelenség katasztrófává válik. Jóval felkészültebbek az emberek a földrengésekre, a viharokra, az áradásokra, és az egyéb természeti katasztrófákra, mint öt évvel ezelött, derül ki a 2012 és 2016 közötti időszakot elemző kockázati világjelentésből is [4]. ,Sok országban tanultak a korábbi természeti katasztrófákból, és javítottak a katasztrófákat megelőző intézkedéseken, ennek ellenére a szélsőséges időjárási jelenségek, mint a viharok és a zivatarok száma, feltünően növekszik" állapítja meg a tanulmány. Ugyanakkor a katasztrófák következményeinek felszámolása nem egy szervezet vagy intézmény, esetleg egy ágazat feladata, hanem szerepe van benne a társadalom más szereplőinek is. A megállapítás alapján feltételezhető, hogy pusztán a védelmi rendszerek fejlesztésével nem kezelhető természeti katasztrófák kérdése. Szükséges az integrált környezet- és a katasztrófavédelmi megközelítés.

Környezetvédelmi kockázatok és a lakosságvédelem összefüggései c. kutatás $[5 ; 112$. o.] megállapítja, hogy" Az emberi élet egyik törvényszerüsége a fejlödés. Az ember kezdetekben még szoros kapcsolatban volt az élö környezettel, vigyázott az értékeire, hiszen ez jelentette a túlélést, majd ez az egyensúly a fejlödés révén felborult, és miközben az emberiség egyes veszélyeket elháritott, de a fejlödéssel párhuzamosan újakat is teremtett magának”. Egyértelmü 
tehát a környezeti károk és az ember természetátalakító termelö munkája közötti az összefüggés, így a megelőzésre nagy hangsúlyt kell fektetni Fontos továbbá az éghajlatváltozással összefüggő veszélyhelyzetek, köztük a katasztrófákkal szembeni reziliencia növelése. Az éghajlatváltozás hatásait és következményeit több nemzetközi szervezet is vizsgálta, így mára már jó körvonalazhatók. Az éghajlatváltozással kapcsolatos katasztrófák között meg kell említeni a rendkívüli esőzéseket, viharokat, az extrém hideget, a hosszantartó szárazságot, és az esőzések következtében kialakuló villámárvizeket, valamint a jégtorlódások következtében kialakuló árvizeket. Az alábbi táblázatban összefoglaltam. [6, 245. oldal] Dr. Földi László tanulmánya szerint.

\begin{tabular}{|c|c|c|c|c|}
\hline \multirow{3}{*}{$\begin{array}{c}\text { Hatások } \\
\text { következmények } \\
\\
\begin{array}{c}\text { Meteorológiai } \\
\text { hatások }\end{array}\end{array}$} & \multicolumn{4}{|c|}{ Hatástípusok } \\
\hline & \multicolumn{2}{|c|}{ Hőmérséklet } & \multicolumn{2}{|c|}{ Csapadék } \\
\hline & $\begin{array}{l}\text { Extrém } \\
\text { magas }\end{array}$ & $\begin{array}{l}\text { Extrém } \\
\text { alacsony }\end{array}$ & $\begin{array}{c}\text { Tartós esőzés, } \\
\text { Hóesés }\end{array}$ & $\begin{array}{l}\text { Tartós } \\
\text { Csapadék- } \\
\text { hiány }\end{array}$ \\
\hline $\begin{array}{c}\text { Hidrológiai } \\
\text { következmény }\end{array}$ & $\begin{array}{l}\text { Vízfelület } \\
\text { párolgási } \\
\text { veszteség }\end{array}$ & Jegesedés & Árvíz Belvíz & $\begin{array}{l}\text { Meder és } \\
\text { élővíz } \\
\text { pusztulás }\end{array}$ \\
\hline $\begin{array}{l}\text { Talajra ható } \\
\text { következmény }\end{array}$ & $\begin{array}{l}\text { Aszály } \\
\text { sivatagosodás } \\
\text { Talajsüllyedé } \\
\text { s }\end{array}$ & $\begin{array}{l}\text { Talaj felületi } \\
\text { repedések } \\
\text { szakadás } \\
\text { szikla törés, } \\
\text { omlás }\end{array}$ & $\begin{array}{l}\text { Sárfolyam } \\
\text { föld- } \\
\text { csuszamlás }\end{array}$ & Sivatagosodás \\
\hline $\begin{array}{l}\text { Társadalomra } \\
\text { ható } \\
\text { következmény }\end{array}$ & \multicolumn{4}{|c|}{$\begin{array}{l}\text { Társadalmi müködési zavarok, egészségi, pszichikai, fizikai károk } \\
\text { Kritikus infrastruktúra sérülése, közüzemi, és egyéb ellátó } \\
\text { szolgáltatások zavarai, }\end{array}$} \\
\hline $\begin{array}{l}\text { Épített } \\
\text { környezetre ható } \\
\text { következmény }\end{array}$ & $\begin{array}{l}\text { Épület tüzek } \\
\text { Omlások } \\
\text { törések }\end{array}$ & $\begin{array}{l}\text { Fagytörés, } \\
\text { omlás }\end{array}$ & $\begin{array}{l}\text { Árvíz épület- } \\
\text { és közmü- } \\
\text { Károk }\end{array}$ & $\begin{array}{c}\text { Épület- tüzek } \\
\text { Omlások } \\
\text { törések }\end{array}$ \\
\hline $\begin{array}{l}\text { Természetes } \\
\text { környezetre ható } \\
\text { következmény }\end{array}$ & $\begin{array}{l}\text { Intenzív } \\
\text { vegetáció- } \\
\text { tüzek }\end{array}$ & Fagykárok & $\begin{array}{c}\text { Vegetáció } \\
\text { vízkár Vadkár }\end{array}$ & $\begin{array}{l}\text { Intenzív } \\
\text { vegetáció- } \\
\text { tüzek }\end{array}$ \\
\hline
\end{tabular}

1. táblázat Az éghajlatváltozás hőmérséklet, csapadék következményei. (saját szerkesztés) [6] forrás alapján 


\begin{tabular}{|c|c|c|c|}
\hline \multirow{3}{*}{$\begin{array}{c}\text { Hatások } \\
\text { következmények } \\
\begin{array}{c}\text { Meteorológiai } \\
\text { hatások }\end{array} \\
\end{array}$} & \multicolumn{3}{|c|}{ Hatástípusok } \\
\hline & Légmozgás & \multicolumn{2}{|c|}{ Több tényező kölcsönhatása } \\
\hline & $\begin{array}{l}\text { Szélvihar (orkán, } \\
\text { forgószél) }\end{array}$ & $\begin{array}{c}\text { Felhö-szakadás, } \\
\text { jégeső }\end{array}$ & $\begin{array}{c}\text { Hófúvás, Gyors } \\
\text { olvadás }\end{array}$ \\
\hline $\begin{array}{c}\text { Hidrológiai } \\
\text { következmény }\end{array}$ & $\begin{array}{l}\text { Védmüvek } \\
\text { sérülése }\end{array}$ & Villám árvíz & Árvíz \\
\hline $\begin{array}{l}\text { Talajra ható } \\
\text { következmény }\end{array}$ & $\begin{array}{l}\text { Homok- } \\
\text { löszvihar, } \\
\text { elhordás } \\
\text { eltemetés }\end{array}$ & $\begin{array}{l}\text { Sárfolyam föld- } \\
\text { csuszamlás }\end{array}$ & $\begin{array}{l}\text { Hidro- dinamikai } \\
\text { talajkárok }\end{array}$ \\
\hline $\begin{array}{l}\text { Társadalomra } \\
\text { ható } \\
\text { következmény }\end{array}$ & \multicolumn{3}{|c|}{$\begin{array}{l}\text { Társadalmi müködési zavarok, egészségi, pszichikai, fizikai } \\
\text { károk Kritikus infrastruktúra sérülése, közüzemi, és egyéb ellátó } \\
\text { szolgáltatások zavarai, }\end{array}$} \\
\hline $\begin{array}{l}\text { Épített } \\
\text { környezetre } \\
\text { ható } \\
\text { következmény }\end{array}$ & Viharkárok & $\begin{array}{l}\text { Árvízi épület, } \\
\text { közmükárok }\end{array}$ & $\begin{array}{l}\text { Épület- közmü- hó } \\
\text { és jégterhelés } \\
\text { vízkárok }\end{array}$ \\
\hline $\begin{array}{l}\text { Természetes } \\
\text { környezetre } \\
\text { ható } \\
\text { következmény }\end{array}$ & $\begin{array}{l}\text { Erdőkárok, } \\
\text { kidőlt fák }\end{array}$ & $\begin{array}{c}\text { Növény Kimosás és } \\
\text { Jégkár }\end{array}$ & $\begin{array}{l}\text { Hóteher jegesedés } \\
\text { károk a vegetáció- } \\
\text { ban }\end{array}$ \\
\hline
\end{tabular}

2. táblázat Az éghajlatváltozás légmozgás és több tényező kölcsönhatás következményei. (saját szerkesztés) [6] forrás alapján

A katasztrófák kárterületei rendszerint összetettek, olyan hatásokkal kell számolni, amelyek szükségessé teszik a felszámolásra hivatott mentőerők, valamint a védelmi igazgatás rendszerén keresztül más mentőerők, a szolgáltatók, valamint az állampolgárok aktiválását is. A cél tehát a veszélyeztető tényezőkkel kapcsolatos, közösségi és egyéni reziliencia, azaz a rugalmas ellenállás fejlesztése.

\section{A KÖRNYEZETI VESZÉLYEKKEL SZEMBENI-REZILIENCIA FELÉRTÉKELŐDÉSE}

A környezeti veszélyekkel szembeni reziliencia fejlesztése csökkentheti az alapvető rendszerek sebezhetőségét (vulnerabilitás). A sebezhetőség sok területen megjelenik. A sebezhetőséget itt az éghajlatváltozás hatására létrejövő károk kiterjedésének vonatkozásában vizsgáljuk. Feltételezhető, hogy a vulnerabilitást nemcsak a rendszer érzékenysége adja, hanem a rendszer adaptációs, ellenállási, rugalmas alkalmazkodási képességei is befolyásolják, tehát nemcsak a veszélyek, kockázatok csökkentése a lehetséges megoldás. A reziliencia fontosságát növeli, hogy az éghajlatváltozás hatásai által keltett kockázatok, nagyrészt hosszú távon, és a jelentős erőforrásokat igényelve, nemzetközi, társadalmi megegyezés eredményeként lehet csökkenteni. Az éghajlatváltozás várható magyarországi hatásainak, természeti és társadalmi-gazdasági 
következményeinek, valamint az ökoszisztémák és az ágazatok éghajlati sérülékenységének értékelése a NÉS- $2^{3}$ részét képezi.

Az alkalmazkodás és felkészülés koncepcionális keretei érintik többek között a vízgazdálkodás, az erdőgazdálkodás, a vidékfejlesztés, az egészségügy, az energetika, a közlekedés, a turizmus, és más ágazatok éghajlatbiztonsággal kapcsolatos helyzetét, kockázatait, a felkészülés lehetséges cselekvési irányait [7].

A reziliencia növelése tehát átfogó szemléletet és tevékenységet igényel. Fejlesztésének fontosságát hangoztatja a VAHAVA kutatások keretében készült tanulmányában Dr. Zellei Gábor, és Dr. Hornyacsek Júlia [8; 82. o.]. „A tény, hogy a globális éghajlatváltozás elsödleges, és másodlagos hatásai kapcsán kialakult veszélyhelyzetek száma folyamatosan nö, és ezzel nönek az emberi, és gazdasági veszteségek is. Az okokat kutatva elmondható, hogy az emberi élet és az anyagi javakban bekövetkezett veszteség, csak részben adódik a veszélyhelyzetböl, jelentös részét az okozza, ahogy a lakosság, és gyakran a mentöerök sem kellöen felkészültek arra, hogy megelözzék a veszélyeket, illetve a kialakult veszélyben a számukra legkedvezöbb eredményt hozó cselekvési mechanizmust tudjanak beinditani". Az egyre inkább tért nyerő „reziliencia tudomány” több tudomány-területen párhuzamosan fejlődik. Kifejezetten elötérbe került az elmúlt időszak klíma-okokra visszavezethető válságainak értékelése során (például Duna-, Elba-árvizek, extrém időjárás stb.).

Alapvetés, hogy ezekben a folyamatokban a civil és humanitárius szervezeteknek jelentős szerepe van. A felvetés aktualitását mutatja az Európai Unió Horizont 2020 program ${ }^{4}$, amely szintén civil támogatásra épülő tevékenység. A program keretében kapott Duna-régió reziliencia tudásanyag-csere hálózat projekt (DAREnet H2020-SEC-21-GM-2016/2017 DAnube river region Resilience Exchange Network) [9]. A DAREnet célja az árvízveszély csökkentése, a beruházást támogató hálózat tervezése és megvalósítása a szakemberek számára a Duna vízgyüjtő területén. Ennek keretében fö feladat a közös innovációs stratégiák kidolgozása és a fokozott együttmüködés kialakítása. A projekt célkitűzése továbbá, a tudományos kutatás támogatásával az árvízveszély csökkentése a Duna-menti országokban. Több más kezdeményezés is a reziliencia fejlesztésének elősegítését tüzte célul, például a Stockholm Resilience Center ${ }^{5}$, mely több projekt indításával járult hozzá a célkitüzések megvalósításához. A reziliencia fejlesztésének, stratégiai céljainak megvalósíthatóságának a feltétele, a megfelelő társadalom gazdasági, anyagi, szellemi, szakmai, és tudományos, kapacitásainak felhasználása. A fejlesztés hatékonyságának másik fontos feltétele a megfelelő önkéntes szervezeti háttér. Az ellenállóképesség fejlesztésének lehetőségei, két jól elkülöníthető területen jelentkeznek, az egyik a humán, a másik a technológia. Mindkét terület rendkívül kiterjedt, a gyorsan változó kihívások növekvő igényeket vetnek fel. Ezen igények komplex vizsgálata nem célom, de a humán fejlesztési terület fontos része a társadalom önkéntes erőforrásainak fejlesztése is, ezért erre fókuszálok.

\footnotetext{
${ }^{3}$ NÉS-2: a második hazai Nemzeti Éghajlatváltozási Stratégia. tartalmazza az üvegházhatású gázok kibocsátáscsökkentési céljait, prioritásait és cselekvési irányait meghatározó tényezőket, feladatokat 2050-ig [7]

${ }^{4}$ Az Innovációs Unió Stratégia a kutatás és az innováció közötti szinergiák megteremtésével a Horizont 2020 program a Kiváló tudomány, az Ipari vezető szerepe és a Társadalmi kihívásokra adott válasza témára helyezi a hangsúlyt [10]

${ }^{5}$ Stockholm Resilience Center (SRC) a Nemzetközi Rugalmassági Ellenállási és Fenntarthatósági Központ 2007 ben alakult a Stockholm Egyetem támogatásával [13].
} 


\section{A HAZAI ÖNKÉNTES SZERVEZETEK SZEREPE ÉS FELADATAI A KÖRNYEZETET ÉRŐ NEGATÍV HATÁSOKKAL SZEMBENI REZILIENCIA KIALAKÍTÁSÁBAN}

Az éghajlatváltozás hatásaihoz való alkalmazkodás megvalósításában a civil szervezetek jelentős szerepet tudnak vállalni. A nemzeti adaptív kapacitás megteremtése mellett a közösségi adaptív tervezés, és az alkalmazkodási stratégiák megvalósítását jelöli ki feladatnak Catherine Pettengell Climate Change Adaptation (Klíma Változás Adaptáció) [11] tanulmánya, kiemelve a regionális területeken, és helyi szinten a kormányzat, és a civil szervezetek szerepét. A szubszidiaritás ${ }^{6}$ jelentőségét erősíti Magyar Emőke és Scheer Márta [12] tanulmánya, melyben megállapítják.A káros folyamatok mérséklése (hagyományos klímavédelem) csak széleskörü nemzetközi összefogással oldható meg. Az összefogások sikere attól függ, hogy az egyes politikák milyen mértékben teszik magukévá az adott programot, célt, ezért a megvalósulás bizonytalannak mondható. Ezzel szemben a klímaalkalmazkodás egyéni és helyi közösségi intézkedésekkel is kezelhetö, melyek ugyan lokálisak, de eredményesek. A megváltozott éghajlathoz való alkalmazkodás letéteményesei tehát az egyének és a helyi közösségek lehetnek, minden közösség saját módszerek kialakításával. Ennél fogva az egyének és a helyi közösségek szintjén a jelenleginél sokkal több tudásra és szándékra van szükség.". A nemzeti adaptív kapacitás létrehozása erősítése tehát fontos feladat, ami a jelenlegi civil szervezetek bázisán, a hálózati eszközök igénybevételével tünik az $\mathrm{NGO}-\mathrm{k}^{7}$ számára hatékonyan megvalósíthatónak.

A civil társadalom alapvetően érzékeny a környezeti problémákra. A civil mozgalmak jelenléte a demokrácia indikátora és hatékony eszköze. Az önszerveződések tagjai sokkal érdekeltebbek, szervezettebbek, könnyebben elérhetőek, megszólíthatóak, és az átlagosnál jóval aktívabbak a környezetvédelem témáiban, mint az egyes emberek. A környezeti ártalmak, és ezen belül az éghajlatváltozás hatásaival szembeni reziliencia egyrészt mitigáció ${ }^{8}$ tevékenység. az éghajlatváltozást okozó tevékenységek vonatkozásában korlátozások bevezetése, veszélycsökkentés, megelőzés és adekvát reagálási, kérdés. Másrészt alkalmazkodás, klímaadaptáció ${ }^{9}$. Ennek feltételeinek meghatározása és megteremtése össztársadalmi feladat. Az adaptáció jelentős pillére a humán erőforrás és a korszerü eljárásmódok és technológia. A negatív hatások és következmények enyhítése, csillapítása, két kiterjedt feladatrendszeren keresztül a megelőzés, prevenció és a felkészülés kereteiben valósul meg. A környezetvédelmi megelözés területén több szervezet, jelentős társadalmi erőként jelenik meg. Jelen vannak a területen a nagy nemzetközi szervezetek, a regionális, és a helyi önkéntes szervezetek egyaránt.

\footnotetext{
${ }^{6} \mathrm{Az}$ elv, mely szerint minden döntést és végrehajtást a lehető legalacsonyabb szinten kell meghozni, ahol a legnagyobb hozzáértéssel rendelkeznek.

${ }^{7}$ A civil szervezet nemzetközi rövidítése. Olyan társadalmi szervezet, amely nonprofit módon, a kormányzattól függetlenül, önkéntes alapon a közjó javára müködik, önszabályozó, intézményesült önszerveződés. nem kormányzati szervezeteknek (angolul non-governmental organization, NGO)

${ }^{8}$ veszély- és negatív hatás csökkentés, enyhítés, csillapítás értelemben használom.

${ }^{9}$ Alkalmazkodás az éghajlatváltozáshoz, melynek lényege, hogy olyan módon segítsük elő a szélsőséges időjárási viszonyokhoz történő alkalmazkodást, hogy közben a károkat minimalizáljuk és az ezzel összefüggő előnyöket kiaknázzuk, teljesítve a fenntartható fejlődés követelményeit.
} 
A Holocén Természetvédelmi Egyesület ${ }^{10}$ például élen jár ebben a munkában. Mind a hatósági megelőzést támogató, mind a környezeti szemléletformáló, és környezettudatosságot növelő tevékenységük kiemelkedő. A borsodi iparvidéken kiemelkedő programokat valósítanak meg környezeti nevelési, közösségi szolgálati programoktól, egészen a fiatal pályakezdők támogatásáig. A társadalom téma iránti érzékenységét mutatja, a Te Szedd! mozgalom. Sikere, hogy 2017-ben 190 ezer önkéntes vállalta lakókörnyezetének megtisztítását, 2240 helyszínen, csaknem 2900 tonna szemetet gyüjtöttek össze. Sok nem kifejezetten környezetvédelmi civil szervezet is részt vett a kezdeményezésben [15].

Az önkéntes szervezetek nagy része a megelőzésben vállal szerepet. Munkájuk jelentős a társadalmi tudatformálás, a környezetszemlélet alakítása, a környezetvédelmi döntésformálás, és a civil-kontroll területén is. A környezettudatosság erősítése is hosszú évek óta jelen van a tevékenységükben. A Magyar Polgári Védelmi Szövetség például a lakosságfelkészítésben, elsősorban a tanulóifjúság környezettudatos magatartásának kialakításában vállalt szerepet, emellett a településeken szervezett polgári védelmi gyakorlatok során arra törekszenek, hogy védettebbé tegyék a közösségeket a rendkívüli időjárással szemben. [16]

A reziliencia mérhetö érték, amit a veszélyeztető tényezők a lehetséges hatásások elviselésére irányúló rugalmas alkalmazkodás adaptáció mennyisége és minősége és az érintett lakosság veszélyek elleni beavatkozó kapacitás nagysága felszereltsége és kiképzetsége alapján lehet számba venni. Az önkéntes szervezetek reziliencia-növelö feladata egyrészt a lakosság felkészítése veszélyhelyzet esetén követendő ajánlások tudatosítása, másrészt a veszélyhelyzetek során beavatkozó önkéntes szervezetek kapacitásfejlesztése. Mindkét feladat szorosan kapcsolódik a katasztrófavédelem polgári védelmi feladatrendszeréhez is. A polgári védelem alapvető feladata a lakosságvédelem és a létfontosságú anyagi javak védelme.

„A környezet részét képezik az ember és az alapvetö anyagi javak is. Ezek védelmét hazánkban (a katasztrófavédelem területéhez tartozó) lakosságvédelmi tevékenységen keresztül hajtják végre. Ebböl adódóan a környezetvédelem és a lakosságvédelem egymással összefüggö, bizonyos területeken egymásra kölcsönösen ható területek” [17, 129. oldal]

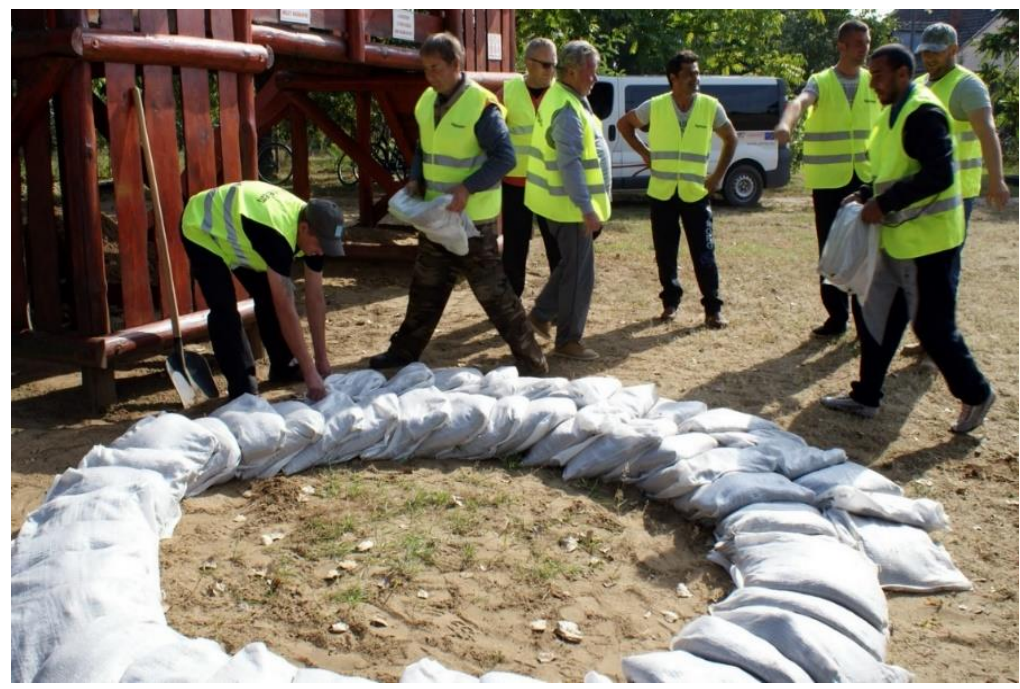

1. ábra Zemplén Térségi Katasztrófa és Polgári Védelmi Szövetség lakosság felkészítő gyakorlata [18]

10 1979-ben létrejött miskolci természet és környezetvédő szervezet. 
A természeti katasztrófák jelentős része az éghajlatváltozás következtében jön létre. A lakosság káreseményekre történő felkészítése nem a kiváltó okokra, hanem az ellensúlyozandó hatásokra épül. Célja, a katasztrófa adaptáció eszközeivel a közösségek érzékenységének csökkentése. Ezen területen nemzeti szinten a Magyar Polgári Védelmi Szövetség, és területi szervezetei szintén jelentős erőfeszítéseket fejtenek ki. "A polgári védelem, mint intézményrendszer, kialakulásától kezdve két pilléren nyugszik: az állami polgári védelmi szervek munkáján, valamint a civil polgári védelmi és egyéb szervezetek tevékenységén. ” [19, 170. oldal]

A civil szervezetek szervezettségüknél, tapasztalataiknál, hagyományaiknál fogva alkalmasak és képesek a védelmi rendszerben aktív és hatékony szereplöként támogatni a hivatásos szervezetek munkáját. Helyismeretünk és kapcsolati rendszerük jól segíthet a megelőzési feladatok meghatározásában, a védelmi feladatokkal kapcsolatos döntések meghozatalában.

\section{A CIVIL SZERVEZETEK ÁLLOMÁNYÁNAK FEJLESZTÉSÉT CÉLZÓ PROGRAMOK}

Az önkéntes szervezetek hatásos tevékenységének egyik legfontosabb feltétele, a magas szintü humán erőforrások alkalmazása. Az önkéntes szervezetek reziliencia mitigációs feladatainak elvégzéséhez szükséges kapacitások közül a képzett és felkészült, önkéntes szakember a legfontosabb, mert az eszköz és anyag szükségletek biztosítása egyszerübb feladat. Az önkéntes humánerőforrás-fejlesztés biztosítja a müveletekben résztvevők leghatékonyabb szervezeti és egyéni felkészítését. Az önkéntes fejlesztés követelményei, közel azonosak a hivatásos állománnyal szemben támasztott elvárásokkal.

A hatásos védelem, a felkészült, veszélyeket ismerö lakosság mellett jól felkészült, és jól felszerelt beavatkozó állományt igényel. Az önkéntes szervezetek fontos szerepet játszanak a katasztrófák elleni védelemben, melyet jól bizonyít a támogatási rendszer. „A központi költségvetésben a tavalyinál százmillióval több, összesen hétszázmillió forint áll rendelkezésre az önkéntes tüzoltó egyesületek és az önkéntes mentőszervezetek támogatására." számolt be a magyar sajtó, és olvasható a szervezet honlapján is. [20]

Az önkéntes szervezetek éves támogatási rendszere mellett, jelentősen megnövekedett az utóbbi években, az önkéntes szervezetek fejlesztését szolgáló projektek száma is. Az önkéntes szervezetek kapacitásait jelentősen növelö fejlesztések közül két programot említhető gyakorlatként. Az egyik az önkéntes mentőszervezetek felkészítése, a KEHOP-1.6.0-15-201600017 azonosító számú projekt keretében. A program megvalósulása, az önkéntes mentőszervezetek eszközállományának tekintetében jelentős előrelépést hozhat. A civil szervezetek humán-erőforrás fejlesztése szintén a projekt célja csak jól felkészült önkéntesek tudnak hatékonyan beavatkozni a korszerű felszerelést kezelni. A projekt céljai között szerepel a védőfelszerelések beszerzése kétszáz szervezet, több mint négyezer-háromszáz önkéntes részére, és a kárelhárítást támogató technikai eszközök számának, illetve a logisztikai kapacitás növelése, továbbá kilencven szervezetnél a beavatkozást támogató, terepjáró technikai eszközök, továbbá húsz szervezetnél az éjszakai munkavégzés, és a helyszíni pihentetés feltételeinek biztosításához szükséges eszközök beszerzése. Szintén a célok között szerepel az új eszközök szakszerü alkalmazásához kapcsolódó tevékenységekhez szükséges ismereteket közvetítő képzések, például a kisgépkezelői, megtartása.

A hazai pályázati lehetőségek mellett, jelentős, a nemzetközi projekt-tevékenység is. Az elmúlt évben ért véget a Katasztrófavédelmi intézményrendszer helyi szintü kapacitásfejlesztése címü, a Norvég Finanszírozási Mechanizmus által támogatott projekt. A program fó célkitüzése 
a kapacitásbővítés, valamint az emberi erőforrás fejlesztése volt a katasztrófavédelemben, [21] Az önkéntes szervezetek számára az egyik legnagyobb kihívás, a közösség megtartása, és az önkéntes állomány folyamatos fejlesztése. Az állam és a közösségek számára is alapvető érdek, az önkéntes szervezetek alkalmazhatóságának fejlesztése. Alkalmazásuk, a leginkább költséghatékony-megoldás a káresemények kezelése folyamán. Ennek feltétele az értelmes programok kialakítása, a célkitüzések helyes meghatározása, valamint az anyagi és technikai feltételek biztosítása. Hasznos lehet az önkéntesek motivációjának növelése adókedvezményekkel például Németországban több helyi adónem alól mentesít az önkéntes szervezetben vállalt tagság. Több magáncég elsősorban biztosítók, de jelentős áruházi láncok vagy szolgáltatók is kedvezményeket adnak az önkéntes igazolvány felmutatásával. Jó gyakorlatot jelent a már említett DAREnet projekt. A program ütemterve alapján, első feladat a hálózat és a résztvevői rendszer kiépítése. A projekt másik lényeges eleme a helyi hálózatokra épülö vízgyüjtő-területi nemzetek közti együttmüködés. A programot végrehajtó testület elvárása a magyar civilszervezeti partner irányába az önkéntes rezilencia-stratégiák vizsgálata és fejlesztése a Duna mentén. Fontos állomány-növelő és megtartó tényező a közös programok szervezése. Ilyen lehet a felkészítés, a gyakorlatok, a hivatásos szervekkel való együttmüködési projektek, valamint az utánpótlás-fejlesztés különböző lehetőségei, mint a versenyek, fesztiválok, szakmai programok

\section{KÖVETKEZTETÉSEK}

Az éghajlatváltozás hatásai napjaink meghatározó tényezőivé váltak. Áttekintve a környezet biztonságát és a fenntartható fejlődés folyamatosságát. Megállapítható, a veszélyeztető tényezőkkel kapcsolatban, az a tény, hogy a szélsőséges időjárási jelenségek, mint a viharok, és a zivatarok száma megnövekedett. A hatásuk, következményeik jelentős anyagi károkkal járnak, és nagymértékben veszélyeztetik alakosság biztonságát. A rendkívüli események negatív következményei elleni védelem, reziliencia fejlesztése alapvető érdeke minden társadalomnak. A védelmi rendszerek fejlesztése nem elegendő. A környezetvédelmi és katasztrófavédelmi kérdésekben szükséges az integrált megközelítés, amely az okokra, következményekre, a válaszadás módjára stb. egyaránt kitér.

Ezért az éghajlatváltozás negatív hatásaival szembeni védekezés érdekében a rugalmas alkalmazkodási stratégiák fejlesztése igazolható szükséges feladat. A reziliencia-fejlesztés hatékonyságát növeli az önkéntes szervezetek alkalmazása, mind a mitigáció, mind az adaptáció területén. Á feltárt következtések alapján, a környezeti okokra visszavezethető káresemények számának, és káros hatásainak növekedése ellentételezésére, szükséges az önkéntes szervezetek tevékenysége. Ezek előnye a szervezettség, a helyismeret, a kapcsolati tőke, melyek révén a döntés-előkészítésben, a megelőzésben és a beavatkozásban egyaránt eredménnyel vehetnek részt. Ebből adódóan az államoknak törekedni kell azoknak a civil szervezeteknek a támogatására, amelyek a veszélyeztető tényezők elleni feladatok végrehajtását vállalják, és készek a mindenkori alkalmazásra.

\section{FELHASZNÁLT IRODALOM}

[1] KAÁN K.: Természetvédelem és a természeti emlékek; Révai Testvérek Irodalmi Intézet Részvénytársaság 1931.

[2] https://zoldgombfesztival.hu/.(letöltve: 2018.03.13.) 
[3] FÖLDI L.: Az éghajlatváltozás hatása a biztonságra és a katonai erö alkalmazására, a hadviselés ökológiai kérdései; Nemzeti Közszolgálati Egyetem, Hadtudományi és Honvédtisztképző Kar, Humánvédelem - békemüveleti és veszélyhelyzet-kezelési eljárások fejlesztése Tanulmánygyüjtemény, Budapest, 2016. 400-474. o.

[4] MUCKE, P.: RADTKE, K.; LUTHER, S. KIRCH, L.PRÜTZ R: Welt Risiko Bericht Analyse und Ausblick; Bündnis Entwicklung Hilft 2017. pp.8.

[5] NAGY S.: HORNYACSEK J.: Környezetvédelmi kockázatok és a lakosságvédelem összefüggései; Bolyai Szemle XXIII. 1.(2014) 109-131. o.

[6] FÖLDI L.: A klímaváltozás következményeként megváltozó katasztrófaveszélyeztetettség. Repüléstudományi Közlemények Repüléstudományi Konferencia Különszám, XXV. 2. (2012) 242-252. o.

[7] 1005/2010. (I.21.) Kormányhatározat a Nemzeti Éghajlatváltozási Programról. Budapest. 2010.Második nemzeti éghajlatváltozási stratégia 2014-2025, kitekintéssel 2050-re. http://nak.mfgi.hu/sites/default/files/files/NES final 131016 kikuld kozig egyeztetes. pdf (letöltve: 2018.03.13.)

[8] ZELLEI G.: HORNYACSEK J.: Lakosságtájékoztatás, felkészités és kriziskommunikáció a globális klimaváltozás okozta veszélyhelyzetekben. In: Felkészülés éghajlatváltozásra, Környezet Kockázat Társadalom, Az NKFP6-00079/2005. számú kutatási projekt katasztrófavédelmi tematikájú tanulmányainak összefoglalója, Budapest, 2008. 81-83. o.

[9] https://projectsworkspace.eu/sites/DAREnet/SitePages/ProjectHome.aspx(letöltve:2018. 03.13.)

[10] Európai Unió Horizont 2020 program. Nemzeti Kutatási, Fejlesztési és Innovációs Hivatal, honlap http://www.h2020.gov.hu/ (letöltve: 2018.03.13.)

[11] PETTENGELL C.: Climate Change Adaptation. honlap http://docserver.ingentaconnect.com/deliver/connect/oxpp/20530234/v6n2/s1.pdf?expir es $=1521528473 \& \mathrm{id}=0000 \&$ titleid $=72010399 \&$ checksum $=$ FE693E7777068D20ABA0C A34B7598DDB (letöltve: 2018.03.14.)

[12] MAGYAR E.: SCHEER M.: Klímaváltozás és hatásainak csökkentése, klíma adaptáció és kockázat megelözés elösegitése. ÖKO Zrt. Tematikus tanulmány-sorozat, IV. téma. https://www.palyazat.gov.hu/download.php?objectId=52423 (letöltve: 2018.03.14.)

[13] A Stockholm Resilience Center (SRC). honlapja. http://stockholmresilience.org/(letöltve: 2018.03.13.)

[14] Nemzeti Környezetvédelmi Program. szakpolitikai stratégia tervezet. http://20102014.kormany.hu/download/5/c7/11000/IV\%20Nemzeti\%20K\%C3\%B6rnyezetv\%C3\% A9delmi\%20Program.pdf. (letöltve: 2018.03.13.)

[15] Földművelésügyi Minisztérium honlap. http://szelektalok.hu/teszedd/(letöltve: 2018.03.13.)

[16] Magyar Polgári Védelmi Szövetség honlap. http://www.mpvsz.hu/ (letöltve: 2018.03.13.)

[17] NAGY S.: HORNYACSEK J.: Környezetvédelmi kockázatok és a lakosságvédelem összefüggései; Bolyai Szemle XXIII. 1.(2014) 109-131. o.

[18] Zemplén Térségi Katasztrófa és Polgári Védelmi Szövetség felkészítő gyakorlata. Magyar Polgári Védelmi Szövetség Katasztrófavédelmi Intézményrendszer Helyi Szintü Kapacitásfejlesztése.HU11-0006-HU11-PP3-2013 Projekt keretében 
[19] KOZÁK A.: HORNYACSEK J.: A polgári védelem kialakulása, szerepe a katasztrófavédelem egységes rendszerében; Bolyai Szemle XXI.2. (2012) 157-184 o.

[20] Katasztrófavédelem honlap: Az idén hétszázmillió forintra emelkedik az önkéntesek támogatása.http://www.katasztrofavedelem.hu/index2.php?pageid=szervezet_hirek\&hir $\underline{\mathrm{id}=5489}$ (letöltve: 2018.03 .13 .)

[21] Katasztrófavédelem honlap: Pályázatok, projektek, http://www.katasztrofavedelem.hu/index2.php?pageid=szervezet_gazdalkodas_palyazat (a letöltés ideje: 2018.03.13.) 